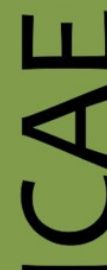

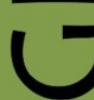

ex Instituto Archaeologico Universitatis de Rolando Eötvös nominatae

O

$\overrightarrow{0}$

山

$\leftarrow$

I

$\cup$

ه

$\leftarrow$

u

Ш

Z

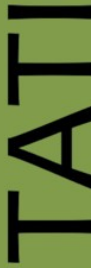

œ

ш

n

n

$\varnothing$
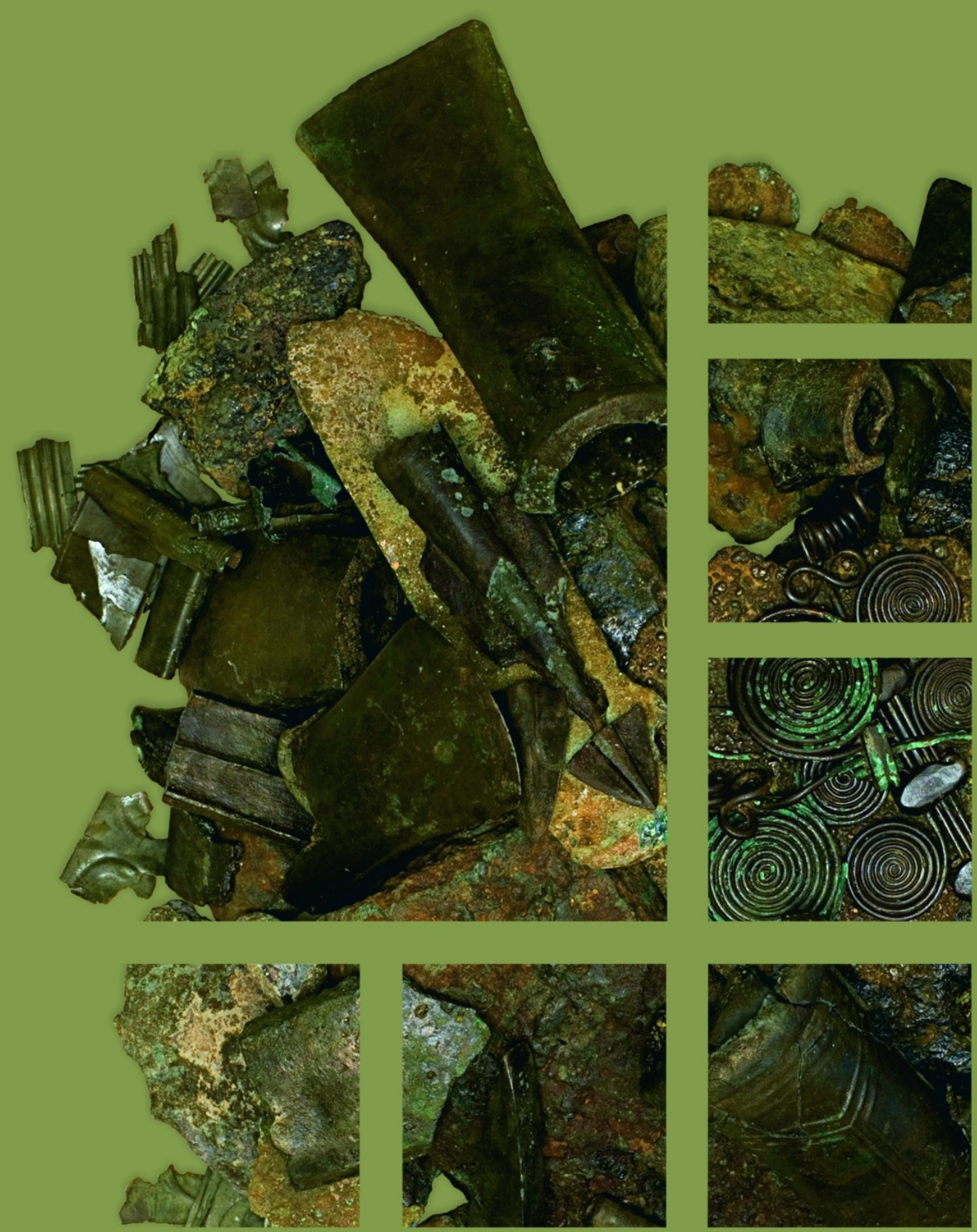


\section{Dissertationes Archaeologicae ex Instituto Archaeologico}

Universitatis de Rolando Eötvös nominatae Ser. 3. No. 2.

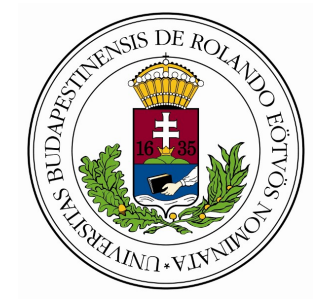

Budapest 2014 
Dissertationes Archaeologicae ex Instituto Archaeologico Universitatis de Rolando Eötvös nominatae

Ser. 3. No. 2.

Editor-in-chief:

DÁvid BARTus

Editorial board:

LÁsZló BARTOSIEWICZ

LÁSZLÓ BORHY

IsTVÁN FELD

GÁBOR KALLA

PÁL RACZKY

MiKLÓs SzABÓ

TIVADAR VIDA

Technical editors:

DÁvid BARTus

GÁBOR VÁCZI

ANDRÁs BÖDŐCS

DÁNIEL SZABÓ

Proofreading:

SZILVIA SzÖLLősI

Available online at http://dissarch.elte.hu Contact: dissarch@btk.elte.hu

$$
\begin{aligned}
& \text { PUBLIC } \\
& \text { KNOWLEDGE } \\
& \text { PROJECT }
\end{aligned}
$$

(c) Eötvös Loránd University, Institute of Archaeological Sciences

Budapest 2014 


\section{Contents}

\section{SElected PAPERS OF THE XI. Hungarian CONFERENCE on Classical Studies}

Ferenc BARNA

Venus mit Waffen. Die Darstellungen und die Rolle der Göttin in der Münzpropaganda

der Zeit der Soldatenkaiser (235-284 n. Chr.)

Dénes GABLER

A belsó vámok szerepe a rajnai és a dunai provinciák importált kerámiaspektrumában

Lajos MATHÉDESZ

Római bélyeges téglák a komáromi Duna Menti Múzeum gyújteményében

Katalin OtTOMÁNYI

Újabb római vicusok Aquincum territoriumán

Eszter SÜVEGH

Hellenistic grotesque terracotta figurines. Problems of iconographical interpretation

András SzABó

Some notes on the rings with sacred inscriptions from Pannonia

István VIDA

The coinage of Flavia Maxima Helena

\section{Articles}

Gábor TARBAY

Late Bronze Age depot from the foothills of the Pilis Mountains

Csilla SÁRó

Roman brooches from Paks-Gyapa - Rosti-puszta

András BöDőcs - Gábor KovÁcs - Krisztián ANDERKó

The impact of the roman agriculture on the territory of Savaria

Lajos JuHÁsz

Two new Roman bronzes with Suebian nodus from Brigetio

\section{FIELD REPORTS}

Zsolt MESTER - Norbert FARAGó - Attila KirÁLy

The first in situ Old Stone Age assemblage from the Rába Valley, Northwestern Hungary

Pál RACZky - Alexandra ANDERs - Norbert FARAgó - Gábor MÁRKus

Short report on the 2014 excavations at Polgár-Csőszhalom 
Preliminary Report on the first season of fieldwork in Berettyóúffalu-Szilhalom

Márton SzILÁgyi - András FüZESI - Attila VIRÁG - Mihály GASPARIK

A Palaeolithic mammoth bone deposit and a Late Copper Age Baden settlement and enclosure

Preliminary report on the rescue excavation at Szurdokpüspöki - Hosszú-dúlö II-III. (M21 site No. 6-7)

Kristóf FüLÖP - Gábor VÁcZI

Preliminary report on the excavation of a new Late Bronze Age cemetery

from fobbágyi (North Hungary)

Lőrinc TimÁr - Zoltán CzAJLik - András BöDőcs - Sándor PuszTA

Geophysical prospection on the Pâture du Couvent (Bibracte, France). The campaign of 2014

Dávid BARtus - László Borhy - Gabriella Delbó - Emese SzÁmadó

Short report on the excavations in the civil town of Brigetio (Szőny-Vásártér) in 2014

Dávid BARTus - László BorHy - Emese SzÁMADó

A new Roman bath in the canabae of Brigetio

Short report on the excavations at the site Szőny-Dunapart in 2014

Dávid BARTus - László Borhy - Zoltán CzAjlik - Balázs Holl -

Sándor PuszTA - László RuPNiK

Topographical research in the canabae of Brigetio in 2014

Zoltán CZAJLIK - Sándor BERECKI - László RUPNIK

Aerial Geoarchaeological Survey in the Valleys of the Mureș and Arieș Rivers (2009-2013)

Maxim MoRDovin

Short report on the excavations in 2014 of the Department of Hungarian Medieval

and Early Modern Archaeology (Eötvös Loránd University, Budapest)

Excavations at Castles Čabrad' and Drégely, and at the Pauline Friary at Sáska

\section{Thesis Abstracts}

Piroska Csengeri

Late groups of the Alföld Linear Pottery culture in north-eastern Hungary

New results of the research in Borsod-Abaúj-Zemplén County

Ádám Bíró

Weapons in the 10-11th century Carpathian Basin

Studies in weapon technology and methodology - rigid bow applications and southern import

swords in the archaeological material

Márta DARÓcZI-SzABó

Animal remains from the mid 12th-13th century (Árpád Period) village of Kána, Hungary

Károly BELÉNYESY

A 15th-16th century cannon foundry workshop in Buda

Craftsmen and technology of cannon moulding and the transformation of military technology

from the Renaissance to the Post Medieval Period 
István RINGER

Manorial and urban manufactories in the 17th century in Sárospatak

\section{BIBLIOGRAPHY}

László BORHY

565

Bibliography of the excavations in Brigetio (1992-2014) 


\title{
Preliminary report on the excavation of a new Late Bronze Age cemetery from Jobbágyi (North Hungary)
}

\author{
KRISTÓF FÜLÖP \\ Institute of Archaeological Sciences \\ Eötvös Loránd University \\ fulopkr14@gmail.com
}

\author{
GÁBOR VÁCZI \\ Institute of Archaeological Sciences \\ Eötvös Loránd University \\ vaczigabor@gmail.com
}

\begin{abstract}
During the summer of 2014 an archaeological team of the Institute of Archaeological Sciences of the Eötvös Loránd University participated in the excavations preceding the expansion of main road No. 21 in Nógrád County. ${ }^{1}$ This project provided an opportunity to unearth a section of a large, biritual Late Bronze Age cemetery in the vicinity of the village of Jobbágyi.
\end{abstract}

The cemetery is situated on the edge of a marshy floodplain of the Zagyva River, on a shoreline running North to South (Fig. 1). Based on the excavated burials and the finds collected from the surface, its estimated expansion might cover an approximately $150 \times 300$ metres area. The excavation was carried out in two $20 \times 150$ metre sectors and a narrow trench, in which 207 Late Bronze Age burials came to light. Larger stones and stone piles covering the graves, as well as some burials with urns were visible right under the ploughed soil layer, in a depth of approximately 40 centimetres. The grave pits were southwest-northeast oriented, oblong with rounded corners, and their depth varied between 60 and 140 centimetres. Within the cemetery two densely used areas could be observed with groups consisting of 10-15 burials. These burials laid closely, 1-1.5 metres from eachother within the groups (Fig. 2).

Due to agricultural activities no surface grave marks (piles of stones or burial mounds) could be detected, only scattered stone groups were noticeable on the surface. Smaller stone piles - one metre in diameter, half metre high and often oblong - were observed in their original position in several cases; they were 40-50 centimetres above the recent ground level.

The most frequent burial practice of the Jobbágyi cemetery was scattered cremation, during which remains of the cremated deceased (or parts of the remains) ${ }^{2}$ were strewn onto the bottom of the burial pit, and the vessels were placed around them, often upside-down (Fig. 5.1). Bronze ornaments of the departed - among which bracelets, rings and pins occurred most frequently - were usually placed onto the bones (Fig. 5.4-7). In several cases bronze artefacts were positioned among and on the top of the remains secondarily, completely merged (Fig. 5.6). The way of placing these grave goods on the pyre may have partly resulted from their diverse function and character (the personal objects of the deceased). In the case of a

1 The project was supervised by Gábor V. Szabó, and Katalin Sebők helped our fieldwork, for the support of whom we are very grateful.

2 Concerning the amount of the remains significant differences could often be noted both in the case of scattered cremations and urn burials. It means a broad spectrum of amounts from a symbolic handful to hundreds of gramms. Beyond technical and ritual questions regarding the treatment of the cremations (for example collecting the remains, the way of the cremations until their final placement), this phenomenon clearly highlights the fact that the physical complex of the former body was not necessary for fully representing the deceased when placing him/her into the grave. 
few burials the ashes and bone shards were deposited in some kind of a textile wrapping, which can be concluded from the regular contour of the cremations as well as the large pin once holding the mouth of the textile together (Fig. 5.4). Small, charred wood remains could also be observed among the ashes in some cases; however, the cremation had never taken place in the burial pit itself. Its location is yet unknown, since the place or places of the cremation did not fall into the excavated areas.

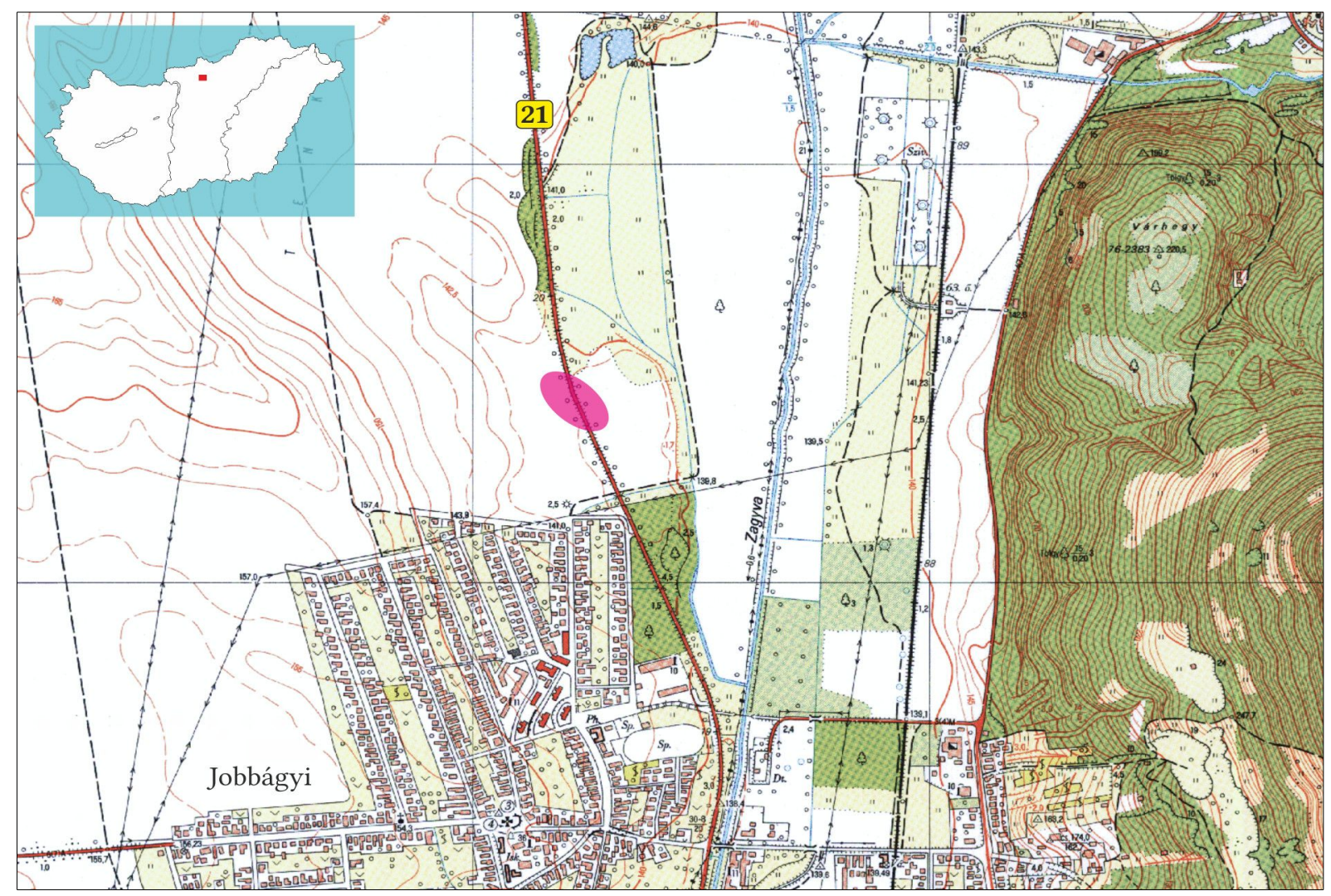

Fig. 1. The location of the Late Bronze Age cemetery in the vicinity of Jobbágyi.

The second most common form of deposition of the cremations was urn burials (Fig. 5.2). The remains were collected from the pyre into a ceramic vessel of the household (storage vessel, amphora, pot or a deep bowl), and no vessels made for this special purpose were used. Urns were usually situated in the middle of the grave pits. In some cases a mug and the bronze ornaments of the deceased were also put into the vessel used as an urn, and then the urn was covered with a bowl or sometimes with a flat stone (Fig. 5.3; Fig. 6.2). In many instances further vessels (small-sized pots, bowls) were placed outside of the urn - either next to it, onto the bottom of the grave pit, or onto its shoulder, in the case of larger urns for example amphorae - which may have been household utensils of the deceased (Fig. 5.2).

Inhumation burial can be considered a secondary burial practice, which constitutes a special element of the cemetery, since only children were buried by this funeral rite. However, compared to cremation burials, no differences can be observed apart from the treatment of the body. The construction of the grave pits is the same, and various pottery as well as bronze ornaments can be equally found among the grave goods. Owing to their age they might have formed a segment of the society which did not involve cremation burial practice, which was only due to grown-up members of the community with a "full" social status (Fig. 6.6). 


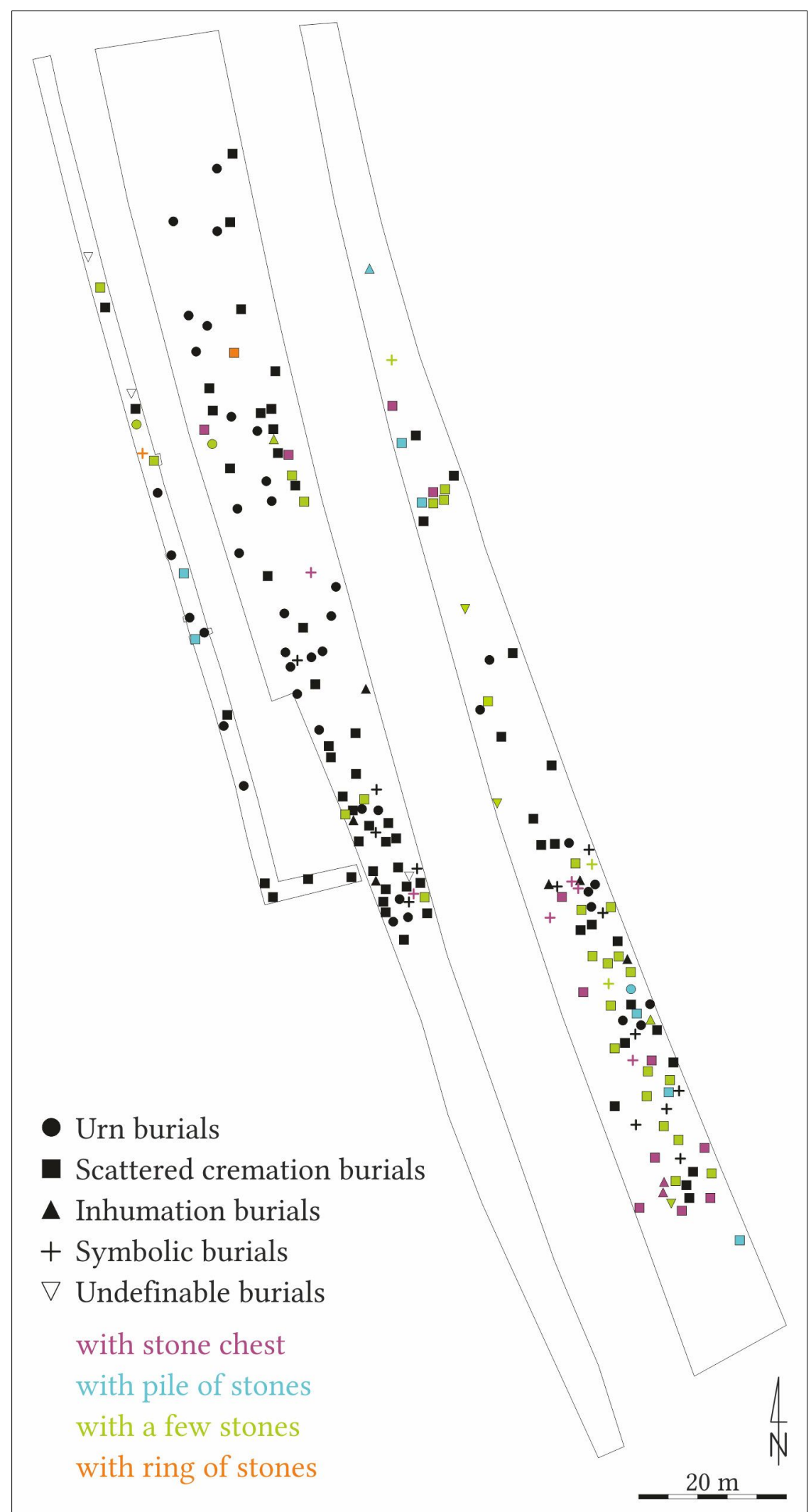

Fig. 2. A schematic map of the cemetery with the various burial practices. 


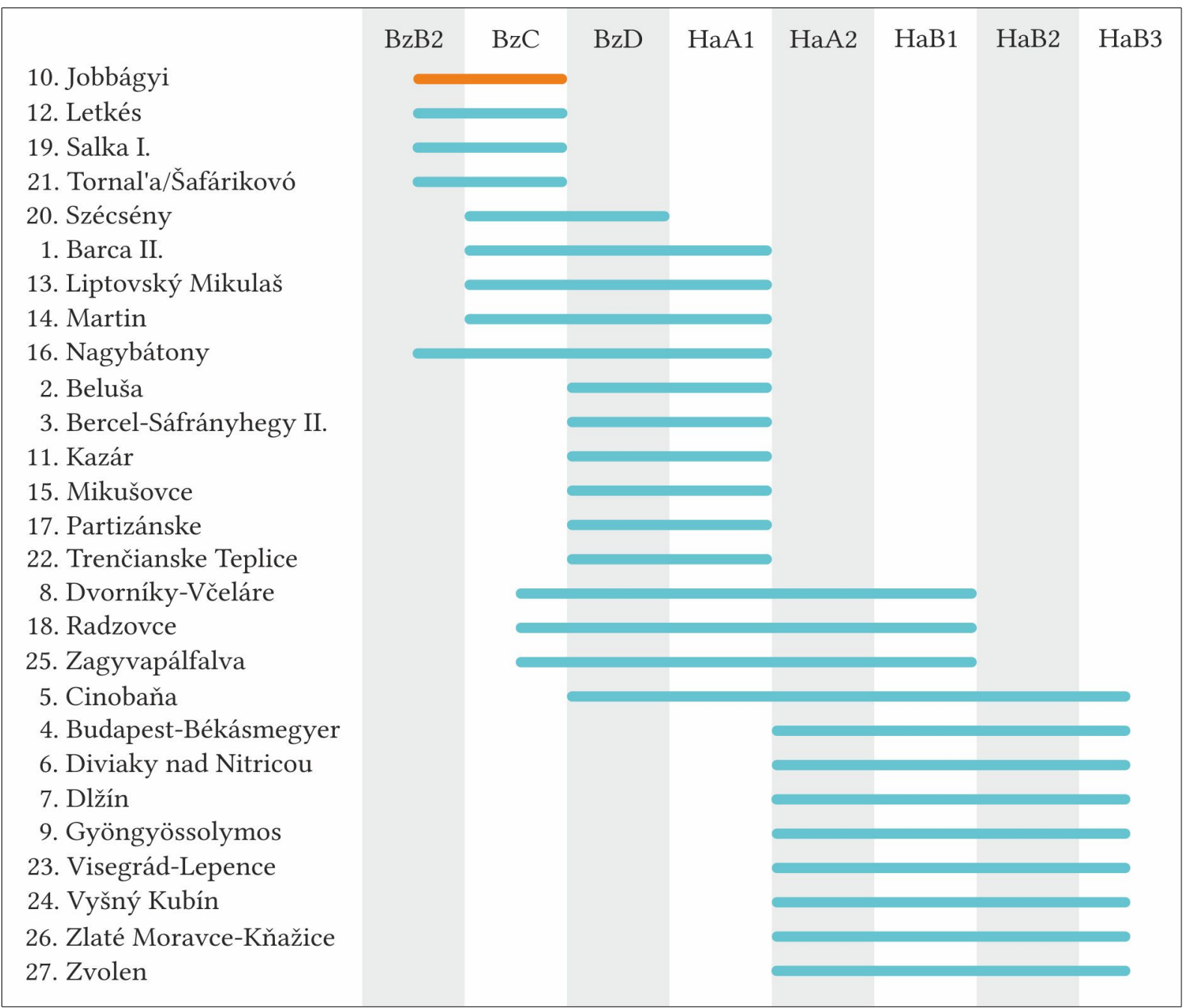

Fig. 3. The chronological position of stone constructions and stone-using burials in the Northern region of the Carpathian Basin.

Beside the graves containing cremations or a skeleton, symbolic burials without human remains also occurred in a small number (Fig. 6.1). In these cases only ceramic vessels were placed into the regularly formed graves, which were often constructed by stones (Fig. 6.3, 5). Some features also came to light which can be interpreted as symbolic graves; however, they differed from them in a few significant aspects. One or two drinking vessels (mugs) were placed into the middle of these smaller, shallow pits with no characteristic shape. An active relation between the departed and the living members of the communities is well documented not only in this period (for example the cemetery of Pitten ${ }^{3}$ ) but in other ones too. These simple, deposited drinking vessels may be the evidences of rituals (for example feasting) taking place during or after burials.

Different forms of stone use can be observed over the entire area of the cemetery; however, group-specific characteristics cannot be revealed (Fig. 2). Most frequently a few ashlars were placed above the grave or into the grave pit beside the cremations (Fig. 5.1; Fig. 6.2). One of its variants is the formation of a large pile of stones on the burial. Another version is when constructing a stone chest, thus putting flat stones set on the edge around the wall of the grave pit, then covering them with one or more large and flat stones (Fig. 6. 3-4). In the case

3 SøRensen et AL. 2008. 
of a simpler version of this complex construction flat stones set on the edge were only placed by the wall of the grave, in a symbolic way (Fig. 6.5-6).

Based on stylistic characteristics of the grave goods the use of this biritual cemetery can be dated to the Late Bronze Age, more precisely to the $\mathrm{BzB} 2-\mathrm{BzC}$ period, and it can be associated with the Tumulus culture. Its grave goods, burial practices and time of usage also confirm that the closest parallel of the Jobbágyi cemetery is the Salka I. cemetery excavated by the Ipoly River. ${ }^{4}$

Among the above presented burial practices the Jobbágyi cemetery differs from other Hungarian Tumulus culture sites in the outstanding and diverse use of stone. Marker stones, rings of stones, piles of stones and stone chests appear in the northern regions of the Carpathian Basin in the beginning of the Late Bronze Age, and they remain in use until the end of the period (Fig. 3). This burial practice, independent of the change of ceramic styles and applied over centuries, can be also found at Tumulus, Piliny, Lausitz, Urnfield and Kyjatice culture sites. The distribution of Late Bronze Age graves with stone constructions is concentrated in an area bordered by the Vág, Hernád and Upper Zagyva Valleys and the Danube Bend (Fig. 4). The graves of the Jobbágyi cemetery with stone constructions represent the southernmost occurrence of this burial rite. The establishment of long-distance relations maintained by those who used this cemetery is most probably due to the significant role of the Zagyva Valley functioning as an important North-South route of cultural and economical interactions.

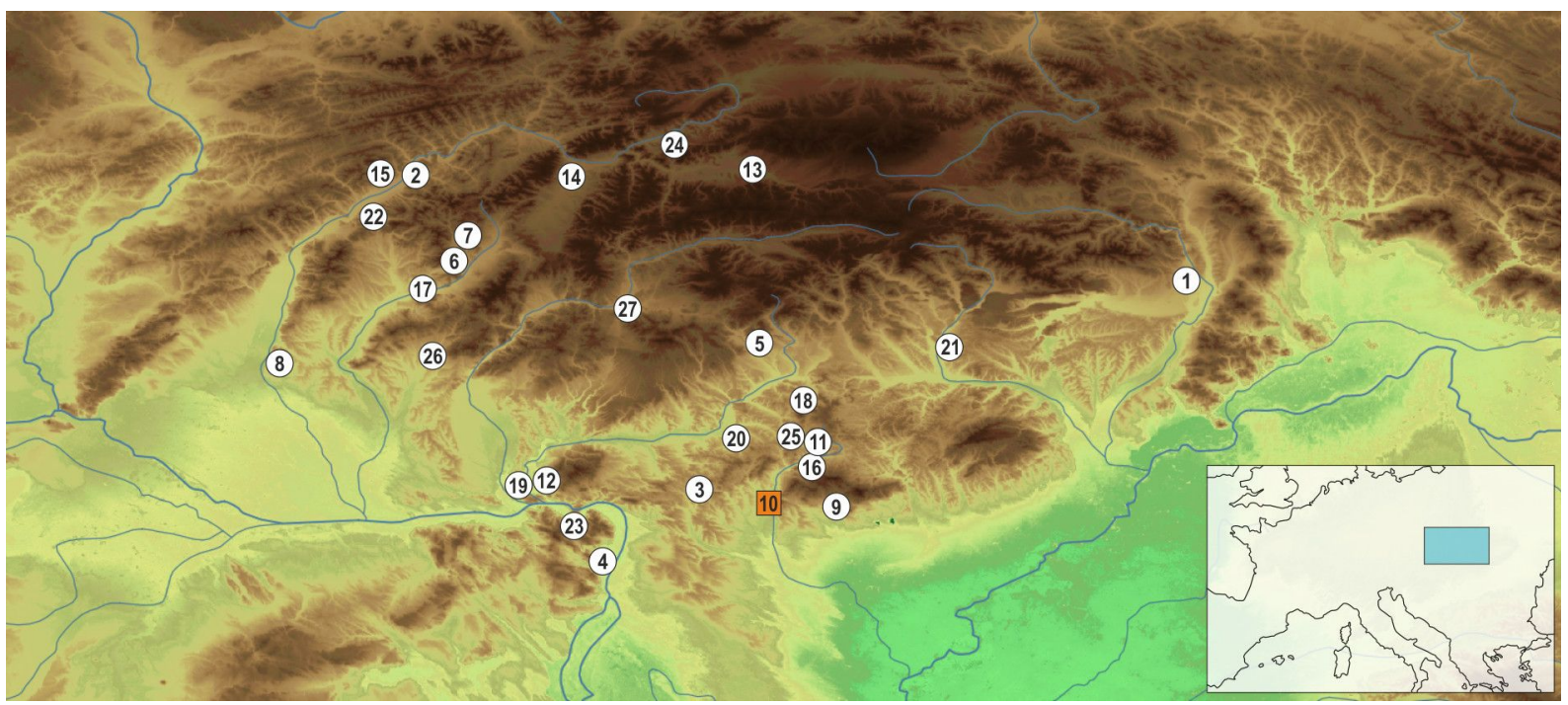

Fig. 4. The location of stone constructions and stone-using burials in the Northern region of the Carpathian Basin. 1. Barca II. (JílkovÁ 1961); 2. Beluša (Furmánek 1970); 3. Bercel-Sáfrányhegy II. (GuBA 2009); 4. Budapest-Békásmegyer (Kalicz-Schreiber-Kalicz 2002); 5. Cinobaňa (FurmÁneK-Mitaš-Pavelková 2010); 6. Diviaky nad Nitricou (Veliačik 1991); 7. Dlžín (BudinskÝ-KRIČKa 1962); 8. Dvorníky-Včeláre (LAMiovÁ-SchmiedlOvÁ 2009); 9. Gyöngyössolymos (PÁsztor 1929); 10. Jobbágyi-Hosszú-dűlő; 11. Kazár (CsAlog-Kemenczei 1966, 81); 12. Letkés (NAGY 1970); 13. Liptovský Mikulaš-Onarašová (Veliačik 1975); 14. Martin (Benkovská-Pivivarová 1975); 15. Mikušovce (Pivovarová 1965); 16. Nagybátony (Patay 1954); 17. Partizánske (Benkovská-Pivivarová 1975); 18. Radzovce (Furmánek 1990); 19. Salka I. (TočIK 1964); 20. Szécsény (Csalog-Kemenczei 1966, 81); 21. Tornal'a/Šafárikovó (FurmÁNEK 1968; 1970); 22. Trenčianske Teplice (PIVovARová 1965); 23. Visegrád-Lepence (Gróf 2009); 24. Vyšný Kubín (ČAplovič 1957); 25. Zagyvapálfalva (Hillebrand 1926; GubA-VAdAY 2008; GubA 2010); 26. Zlaté Moravce-Kňažice (KujovskÝ 1994); 27. Zvolen (BALAšA 1964). 


\section{References}

BALAšA, G. 1964: Zvolen v období lužickej kultúry. Banská Bysrtica.

Benkovská-PivovarovÁ, Z. 1975: Výskum pohrebiska lužickej kulrúry v Partizanskom roku 1958 Unterschung des Gräberfeldes der Lausitzer Kultur in Partizánske im Jahre 1958. Slovenská Archeológia 23, 35-54.

BudiNSKÝ-KRIČKA, V. 1962: Príspevok k študiu kultúry popolnicových polí nad hornou Nitrou - Ein Beitrag zum Studium der Urnenfelderkultur im oberen Nitratal. Študijné Zvesti AÚ SAV 9, 123-130.

ČAPLOviČ, P. 1957: Lužické žiarové hroby pod Skalkou vo Vyšnom Kubiné - Lausitzer Brandgräber unter der Skalka in Vyšný Kubín. Slovenská Archeológia 5, 339-346.

Csalog, Zs. - Kemenczei, T. 1966: A jászberény-cserőhalmi későbronzkori temető - Das spätbronzezeitliche Gräberfeld von Jászberény-Cserőhalom. Archaeologiai Értesitő 93, 65-97.

FurmÁnek, V. 1968: Piliňské žárové pohřebiště v Šafárikově, okr. Rimavská Sobota - Das Pilinyer Brandgräberfeld in Šafárikovo, Kr. Rimavská Sobota. Archeologické rozhledy 20, 3-11.

FuRMÁNEK, V. 1970: Další výzkum na piliňském žárovém pohřebišti v Šafárokově - Weitere Abdeckung des Brandgräberfeldes des pilinyer Kultur in Šafárokovo. Východoslovenský Pravek 1, 49-55.

Furmánek, V. 1990: Radzovce. Osada l’udu popolnicových polí. Bratislava.

Furmánek, V. - Mitaš, V. - Pavelková, J. 2010: The burial ground of the Kyjatice culture in Cinobaňa (Slovakia). In: GuBA, Sz. - TANkó, K. (eds.): „Régról kell kezdenünk...”Studia Archaeologica in honorem Pauli Patay. Szécsény, 125-133.

Gróf, P. 2009: Visegrád-Lepence. In: Kisfaludi, J. (ed.): Régészeti Kutatások Magyarországon 2008 Archaeological Investigations in Hungary 2008. Budapest, 314-316.

GubA, Sz. 2009: A pilinyi kultúra temetkezései Bercel-Sáfrányhegy II. lelőhelyen - Das Gräberfeld der Piliny-Kultur aus Bercel-Sáfrányhegy II. Neograd 32, 73-98.

GubA, Sz. 2010: A Zagyvapálfalvai temető közöletlen leletei a Kubinyi Ferenc Múzeum gyűjteményében - Die Altfunde des spätbronzezeitlichen Gräberfeldes aus Zagyvapálfalva in der Sammlung des Ferenc Kubinyi Museums. In: GubA, Sz. - TANKó, K. (eds.): „Régről kell kezdenünk...” Studia Archaeologica in honorem Pauli Patay. Szécsény, 71-93.

GubA, Sz. - VAdAy, Sz. 2008: Többkorszakú lelőhely próbafeltárása Salgótarján-Bevásárlóközpontban. Előzetes jelentés. In: Kisfaludi, J. (ed.): Régészeti Kutatások Magyarországon 2007 - Archaeological Investigations in Hungary 2007. Budapest, 11-34.

Hillebrand, J. 1926: A zagyvapálfalvai bronzkori urnatemető. Archaeologiai Értesító 40, 60-69.

JílkovÁ, E. 1961: Piliňské pohřebiště Barca II a jeho časové a kulturní horizonty - Piliner Gräberfeld Barca II und seine Zeit- und Kulturhirizonten. Slovenská Archeológia 9, 69-106.

Kalicz-Schreiber, R. - Kalicz, N. 2002: Die Steinverwendung bei den Bestattung des spätbronzezeitlichen Gräberfeldes von Budapest-Békásmegyer. Anodos 2, 143-154.

Kujovský, R. 1994: Príspevok k poznaniu vzíahov lužických a stredodunajských popolnicových polí na Slovensku - Beitrag zum Kennen der Beziehungen der lausitzischen und mitteldanubischen Urnenfelder in der Slowakei. Slovenská Archeológia 42, 261-307.

LAMIovÁ-SchmiedlovÁ, M. 2009: Žiarové pohrebisko z mladšej doby bronzovej na lokalite DvorníkyVčeláre - Brandgräberfeld aus der Füngeren Bronzezeit auf der Fundstelle Dvorníky-Včeláre. Archaeologica Slovaca Monographiae Catalogi 11. Nitra. 
NAGY, L. 1970: Letkés, Kertészföldek-Wasserstandsmeldstation. Mitteilungen des Archäologischen Institutes des Ungarischen Akademie der Wissenschaften 1, 110-111.

PATAY, P. 1954: Előzetes jelentés a nagybátonyi temető ásatásának eredményeiről - Preliminary report on the results of excavation at Nagybátony cemetery. Archaeologiai Értesitó 81, 33-49.

PÁszTor, J. 1929: A Mátra. Úti kalauz. Történeti és természeti nevezetességek ismertetése. Budapest.

PivovarovÁ, Z. 1965: K problematike mohýl v lužickej kultúre na Slovensku - Zur Problematik der Hügelgräber der Lausitzer Kultur in der Slowakei. Slovenská Archeológia 13, 107-162.

Sørensen, M. L. S - Rebay-SAlisbury, K. 2008: From substantial bodies to the substance of bodies: analysis of the transition from inhumation to cremation during the Middle Bronze Age in central Europe. In: Borić, D. - RoвB, J. (eds.): Past Bodies: Body-Centered Research in Archaeology. Oxford, 59-68.

TočıK, A. 1964: Die Gräberfeld der Karpatenländischen Hügelgräberkultur. Fontes Archaeologici Pragenses 7. Praha.

Veliačik, L. 1975: Pohrebisko lužickej kultúry v Liptovskom Mikuláši-Ondrašovej - Gräberfeld der Lausitzer Kultur in Liptovský Mikuláš-Ondrašová. Slovenská Archeológia 23, 11-34.

VeLIAčıK, L. 1991: Beitrag des Gräberfeldes in Diviaky nad Nitricou zur Chronologie der Denkmäler der Lausitzer Kultur in der Slowakei. Slovenská Archeológia 39, 143-214. 


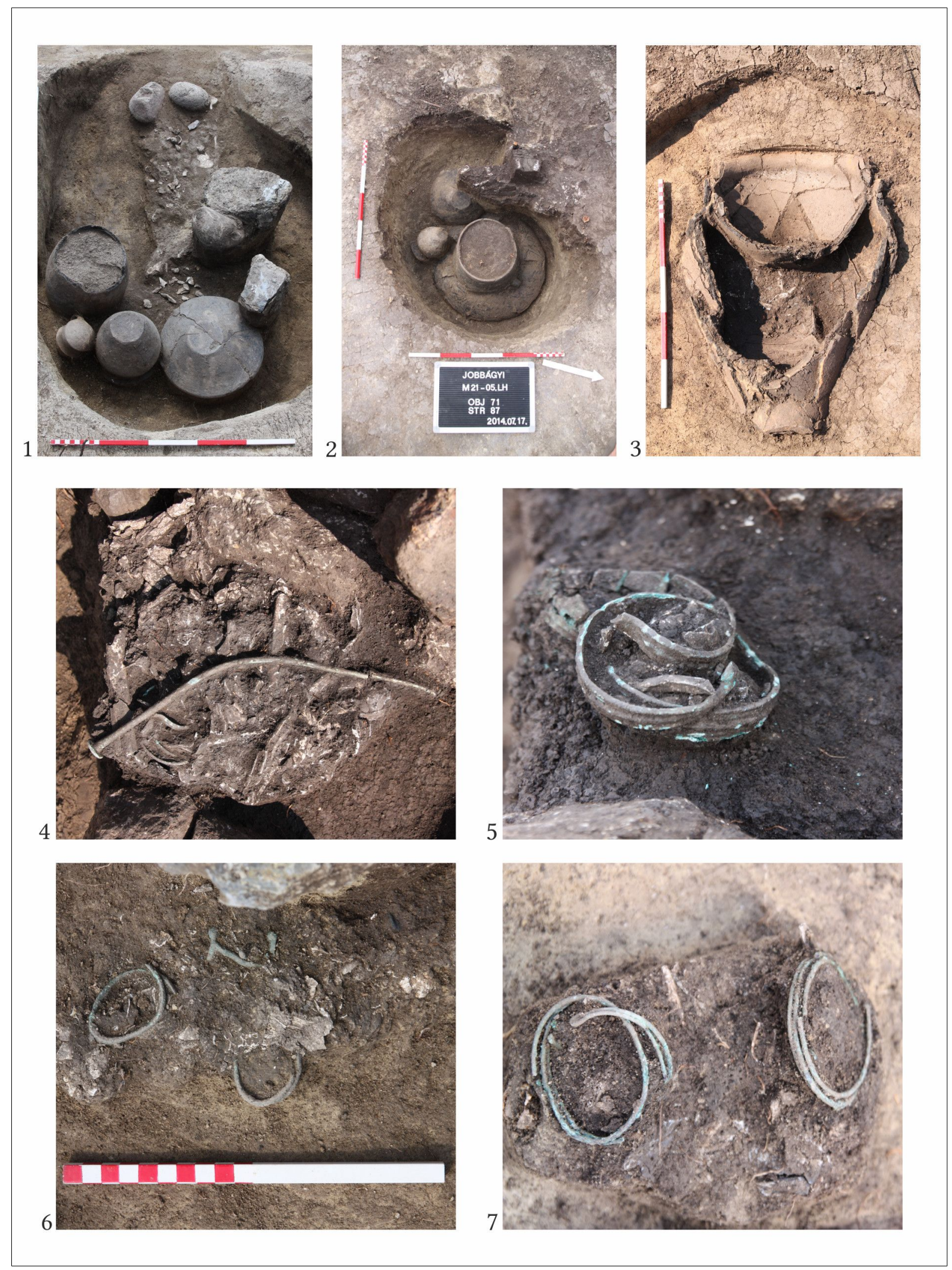

Fig. 5. A selection of the most common burial practices and bronze objects. 


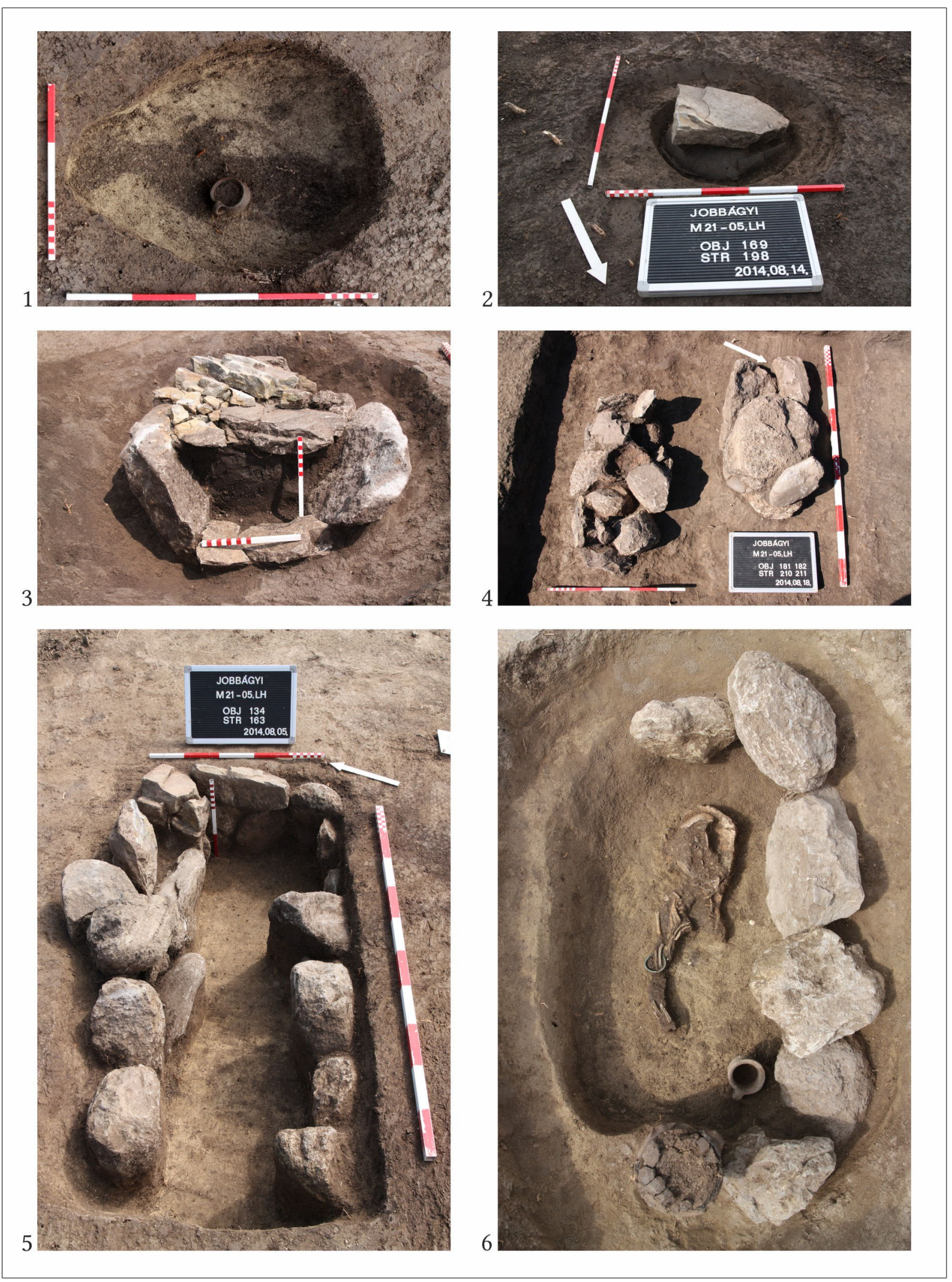

Fig. 6. A symbolic grave (1) and use patterns of ashlars in the burial constructions (2-6). 